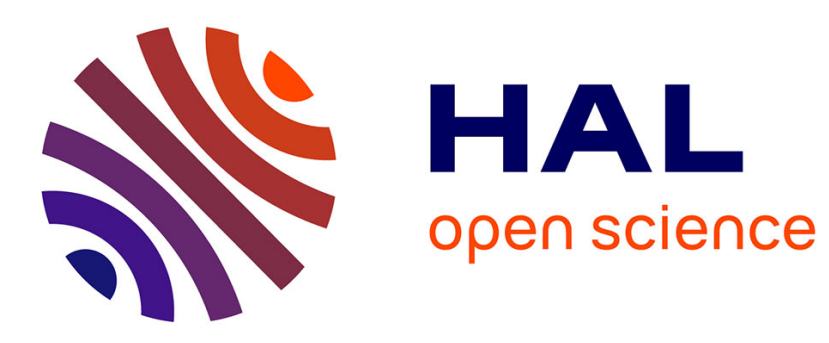

\title{
The Owen Ridge uplift in the Arabian Sea: Implications for the sedimentary record of Indian monsoon in Late Miocene
}

Mathieu Rodriguez, Nicolas Chamot-Rooke, Philippe Huchon, Marc Fournier, Matthias Delescluse

\section{To cite this version:}

Mathieu Rodriguez, Nicolas Chamot-Rooke, Philippe Huchon, Marc Fournier, Matthias Delescluse. The Owen Ridge uplift in the Arabian Sea: Implications for the sedimentary record of Indian monsoon in Late Miocene. Earth and Planetary Science Letters, 2014, 394, pp.1-12. 10.1016/j.epsl.2014.03.011. hal-00966802

\section{HAL Id: hal-00966802 \\ https://hal.science/hal-00966802}

Submitted on 27 Mar 2014

HAL is a multi-disciplinary open access archive for the deposit and dissemination of scientific research documents, whether they are published or not. The documents may come from teaching and research institutions in France or abroad, or from public or private research centers.
L'archive ouverte pluridisciplinaire HAL, est destinée au dépôt et à la diffusion de documents scientifiques de niveau recherche, publiés ou non, émanant des établissements d'enseignement et de recherche français ou étrangers, des laboratoires publics ou privés. 
PREPRINT Earth and Planetary Science Letters 394 (2014) 1-12

The Owen Ridge uplift in the Arabian Sea: implications for the sedimentary record of Indian monsoon in Late Miocene

Mathieu Rodriguez ${ }^{1 *}$, Nicolas Chamot-Rooke ${ }^{1}$, Philippe Huchon ${ }^{2,3}$, Marc Fournier ${ }^{2,3}$, Matthias Delescluse $^{1}$

(1) Laboratoire de Géologie de l'Ecole normale supérieure de Paris; CNRS UMR 8538, 24 rue Lhomond, 75005 Paris, France

(2) Institut des Sciences de la Terre de Paris, CNRS UMR 7193, Université Pierre \& Marie Curie, case 129, 4 place Jussieu, 75005 Paris, France

(3) iSTeP, UMR 7193, CNRS, F-75005 Paris, France

*Corresponding author: rodriguez@geologie.ens.fr

\section{Abstract}

The pelagic cover of the Owen Ridge in the Arabian Sea recorded the evolution of the Indian monsoon since the Middle Miocene. The uplift of the Owen Ridge resulted from tectonic processes along the previously unidentified Miocene India-Arabia plate boundary. Based on seismic reflection data tied with deep-sea drilling to track the Miocene India-Arabia plate boundary, we propose a new timing for the uplift of the Owen Ridge and highlight its impact on the record of climate changes in pelagic sediments. The new dataset reveals a fracture zone east of the Owen Ridge corresponding to the fossil plate boundary, and documents that the main uplift of the Owen Ridge occurred close to $\sim 8.5 \mathrm{Ma}$, and is coeval with a major uplift of the east Oman margin. Late Miocene deformation at the India-Arabia plate boundary is also coeval with the onset of intra-plate deformation in the Central Indian Ocean, suggesting a kinematic change of India and surrounding plates in the Late Miocene. The uplift of the Owen Ridge above the 
lysocline at $\sim 8.5$ Ma accounts for a better preservation of Globigerina bulloides in the pelagic cover, previously misinterpreted as the result of a monsoon intensification event.

\section{Introduction}

The pelagic sedimentary cover of the Owen Ridge contains the past records of the Asian summer monsoon since the Middle Miocene (Shipboard Scientific Party, 1974, 1989). The ridge itself consists of a series of bathymetric highs sub-dividing the Arabian Sea into an abyssal plain to the east and a shallower Owen basin to the west (Fig. 1). The Arabian Sea is located on the migration path of the Inter Tropical Convergence Zone, which controls the seasonality of the Asian monsoon. The apparent increase in the abundance of the foraminifera Globigerina bulloides within the Owen Ridge's pelagic cover, commonly interpreted as a proxy for monsoon-driven upwelling (Kroon et al., 1991), suggests that the evolution of astronomical parameters alone cannot be responsible for the observed monsoon intensification in the upper Miocene (Molnar et al., 1993; Molnar, 2005; Sun and Wang, 2005; Huang et al., 2007; Clift et al., 2008; Steinke et al., 2010). A Late Miocene uplift of the Himalayan-Tibetan Plateau (Harrison et al., 1992) was proposed as a forcing mechanism over the climatic system, high elevation inducing a reorganisation of the atmospheric circulation and hence, monsoon intensification (Molnar and England, 1990; Molnar et al., 1993; Ann et al., 2001). However, a growing set of observations showed that the Himalaya mountain belt reached its present-day elevation at least $\sim 15$ Myrs ago, and probably earlier (Spicer et al., 2003; Molnar, 2005; Harris, 2006; Rowley and Currie, 2006; Dupont-Nivet et al., 2008; Wang et al., 2012; Yuan et al., 2013).

A re-analysis of marine sediments drilled at the Owen Ridge questioned the record of an apparent monsoon intensification at $\sim 8.5 \mathrm{Ma}$ (Huang et al., 2007). Selecting foraminifera of large size to remove the effect of variations in carbonate dissolution in the abundance records, Huang et al. (2007) document only a minor change in the fraction of G. bulloides near $10 \mathrm{Ma}$. The latter is consistent with a constant decrease in weathering of India during the Late Miocene (Clift et al., 2001; 2003; 2008). Steinke et al. (2010) even suggested that the Late Miocene was a period of summer monsoon weakening over India, rather than intensification. 
The timing of seafloor uplift in the Indian Ocean is critical to the understanding of the sedimentary record of climate during the Cenozoic. The commonly accepted tectonic framework of the Arabian Sea is that the uplift of the Owen Ridge was coeval with the beginning of accretion at the Sheba Ridge in the Gulf of Aden 20 Ma ago (Fig. 1) (Whitmarsh, 1979) and with the shift of the India-Arabia plateboundary from the Oman continental margin to its present-day location (Mountain and Prell, 1990). However, structural and kinematic studies show that the Owen Fracture Zone (the current plate boundary) is no older than 3 to $6 \mathrm{Ma}$ (Fournier et al., 2008a; 2011; Rodriguez et al., 2011; 2013b). As a result, the location of the India-Arabia plate boundary during the Miocene, as well as its relationship with the uplift of the Owen Ridge, remain unknown.

Here we present a new set of seismic reflection data that documents a Late Miocene tectonic uplift at the edges of the Owen Basin, including the Owen Ridge. We identify the Miocene India-Arabia plate boundary and highlight the tectonic processes at the origin of the Owen Ridge uplift. We finally discuss how the latter impacted the record of climate evolution in the pelagic sediments of the Arabian Sea.

\section{Materials and methods}

The dataset presented in this study was acquired onboard the French Navy oceanographic vessel Beautemps-Beaupré during the OWEN and OWEN-2 surveys run in 2009 and 2012 respectively. Multibeam bathymetry was collected using a Kongsberg-Simrad EM 120 echo-sounder (Fig. 1, 2). Seismic reflection profiles were acquired at 10 knots using two GI air-guns (one 105/105 c.i. and one 45/45 c.i., fired every 10 seconds at 160 bars in harmonic mode, resulting in frequencies ranging from 15 to $120 \mathrm{~Hz}$ ) and a 24-channel, 600 m-long streamer, implying a common mid-point spacing of 6.25 m. A sub-surface penetration of about 2s two-way travel time (TWT) was achieved throughout the survey. The processing consisted of geometry setting, water-velocity normal move-out, stacking, water-velocity F-K domain post-stack time migration, bandpass filtering and automatic gain control. All profiles are displayed with a vertical exaggeration of 8 at the seafloor. The seismic dataset is tied with Deep Sea Drilling Project (DSDP) and Ocean Drilling Project (ODP) drillings available in the Arabian Sea (Shipboard Scientific Party, 1974; 1989) to provide the stratigraphic framework (Fig. 3, 
inset). Reflectors picked on seismic profiles have been selected based on seismic discontinuities that reflect lithological changes, stratigraphic hiatuses or tectonic deformation.

\section{Geological framework of the Arabian Sea and the Owen-Murray Ridge System}

\subsection{Present-day morphology of the Arabian Sea}

The Owen Fracture Zone is an 800-km-long strike-slip fault system, which runs along the Owen Ridge (Fig. 1). The southern Owen Ridge is a $300 \mathrm{~km}$-long, 50-km wide, and up to $2000 \mathrm{~m}$-high relief that appears as a vast tilted slab (Fig. 2b). It contrasts with the uneven topography of the $220 \mathrm{~km}$-long, $50 \mathrm{~km}$-wide, and up to $1700 \mathrm{~m}$-high central ridge (Fig. 2a), and the guyot morphology of the Qalhat Seamount further to the north. The Owen Fracture Zone connects seafloor spreading at the Sheba midoceanic ridge with the Makran subduction zone (Fig. 1). At its northern end, the Owen Fracture Zone forms a complex stepover basin known as the Dalrymple Trough (Edwards et al., 2000; Gaedicke et al., 2002), which is flanked to the east by the Murray Ridge. Seafloor spreading at the Sheba Ridge started around $20 \mathrm{Ma}$ (Fournier et al., 2010), whereas subduction in the Makran area began in the Late Cretaceous (McCall, 1997). The modern accretionary wedge developed since the Tortonian (7.2-11.6 Ma) (McCall, 1997; Burg et al., 2008; Smit et al., 2010). Seafloor morphology does not display any trace of the Miocene India-Arabia plate boundary (Rodriguez et al., 2011).

\subsection{Substratum of the Owen-Murray Ridge System}

Several seismic lines run as pre-site surveys for DSDP and ODP reached the basement of the southern and the central ridges. Their uneven substratum, drilled at DSDP Sites 223 and 224 (Fig. 2), is basaltic in composition and of Late Paleocene age (Shipboard Scientific Party, 1974; 1989). These 50-55 Maold reliefs might either be tilted slivers of oceanic crust or volcanic highs (Fig. 3b), and are hereafter referred as the "pre-Owen Ridge". The history of the Murray Ridge basement is not clearly established, since it has never been drilled. Based upon seismic refraction data, the Murray Ridge has been interpreted as a small piece of continental crust inherited from the Gondwana break-up (Edwards et al., 2000; 2008). 


\subsection{Uplift of the Owen Ridge}

112 In its present-day configuration, the southern Owen Ridge is formed at its top by Upper OligoceneLower Miocene turbidites coming from the Indus deep-sea fan and the subsequent pelagic cover (Fig. 3b) (Shipboard Scientific Party, 1974; 1989). Lower Miocene turbidites at the top of the Owen Ridge indicates an episode of uplift during the Miocene, rejuvenating the topography of the proto-Owen Ridge.

So far, the uplift of the Owen Ridge has been dated at 20 Ma based on two sets of arguments. The first set of arguments deals with the progressive burial of the proto-Owen Ridge and its pelagic cover by Upper Oligocene-Lower Miocene Indus turbidites, which forms a diachronous angular unconformity (picked in light purple) (Fig. 3) biostratigraphically dated at 19.6 Ma and $\sim 14 \mathrm{Ma}$ at the southern (Fig. 3b) and central (Fig. 3c) Owen Ridge, respectively (Shipboard Scientific Party, 1974). In fact, this angular unconformity is unrelated to any tectonic uplift of the Owen Ridge, in contrast with previous interpretation by Whitmarsh et al. $(1974 ; 1979)$. Second, the transition from Indus turbidites to Miocene pelagic deposits drilled on the southern Owen Ridge at DSDP Site 224 and ODP Sites 721, 722, 731 (top of Unit 4, Fig. 3) has been considered by Mountain and Prell (1990) as an indicator of uplift above the level of turbiditic deposition. The transition is marked by a mixed pelagic-turbiditic sequence biostratigraphically dated at 14-15 Ma, composed of thin detrital particles, interpreted as the uppermost part of the turbiditic plume being deposited during the first stages of ridge uplift (Mountain and Prell, 1990). The latter argument will be revised in the light of our new dataset.

\subsection{Past locations of the India-Arabia plate-boundary}

Past location of the India-Arabia plate boundary prior to the Owen Fracture Zone is currently unknown. Early paleogeographic reconstructions by Whitmarsh (1979) suggested that the IndiaArabia plate boundary was already at its present-day location when India started to move northwards at $\sim 90$ Ma. An alternative paleogeographic reconstruction (Mountain and Prell, 1990) postulates that the India-Arabia plate-boundary initially ran along the Oman continental margin, while the Mascarene

137 Basin opened between Madagascar and Seychelles (between $90-60 \mathrm{Ma}$ ) (Bernard and Munschy, 2000) and the Carlsberg Ridge developed (since $\sim 63 \mathrm{Ma}$; Dyment, 1998). The India-Arabia plate- 
boundary would then have jumped to its present-day position in the Early Miocene ( $20 \mathrm{Ma})$, triggering the uplift of the Owen Ridge (Mountain and Prell, 1990). A Paleogene location of the IndiaArabia plate-boundary in the Owen Basin is also supported by paleogeographic reconstructions based on the record of magnetic anomalies over the Arabian Sea (Royer et al., 2002).

\section{Results}

\subsection{Late Miocene deformation and contourites on the East-Oman margin}

Seismic profiles crossing the edge of the continental platform reveal a large, $\sim 20$-km-wide anticline affecting Lower to Upper Miocene sediments composed of calcareous turbidites according to the nearby ODP Site 730 (units U2 and U3, Fig. 3a and 4) (Shipboard Scientific Party, 1989). A dense network of faults affects the anticline and is sealed by upper Miocene to Plio-Pleistocene deposits (unit U1, Fig. 3a and 4). The folded unit contains planktonic faunas typical of a deep-sea environment (Shipboard Scientific Party, 1989). An erosive surface sealing the top of the anticline (Fig. 3a and 4) indicates local uplift of the platform during the folding episode. At the location of the ODP Site 730, the fold then subsided down below the sea level in early Pleistocene times, as indicated by the age of the first overlying sediments (1.3 Ma). Thick chaotic bodies interpreted as Mass Transport Deposits (MTD hereafter) on Fig. 3a and 4 are observed down the eastern flank of the fold, indicating sudden slope over-steepening related to the formation of the fold. The youngest calcareous turbidites affected by the deformation are $\sim 8.8$ Ma-old according to correlations with ODP Site 730 . The fold is overlaid by $\sim 8.2$ Ma-old sediments according to ODP Site 728 (Shipboard Scientific Party, 1989). This set of observations documents a major uplift episode along the Oman margin around 8.5 Ma.

Bottom currents influenced the architecture of the sedimentary unit U1 sealing the fold (Fig. 3a). Unit 1 displays a complicated set of imbricated, sigmoid to undulating geometries, all non-parallel to the accumulation surface that moved preferentially upslope through times. This description corresponds to a confined drift according to the classification of Faugères et al. (1999), and is very similar to drifts observed along the Algarve Margin (Portugal) (Marchès et al., 2010; Brackenridge et al., 2013).

\section{2. Late Miocene deformation at the Southern Owen Ridge}


An E-W seismic line was acquired close to ODP Site 722 on the Southern Owen Ridge, where the most complete sequence has been drilled (Fig. 3b). A fanning configuration characterizes the lower Miocene turbidites on top of the Owen Ridge (Fig. 3b, 5a, 5b, 6a). The seismic profile crossing ODP Site 722 (Fig. 3b) shows that the 14-15 Ma-old turbiditic-pelagic facies has been drilled on the levee of a fossil turbiditic channel. The $\sim 40$-m-deep channel axis is identified by a typical lens-like architecture and discontinuous, high-amplitude reflections. The associated levees display a characteristic wedge shape with high-amplitude, transparent seismic facies (Fig. 3b).

The sedimentary cover overlying the last turbiditic channel (units U3 to U1) is composed of pelagic deposits (Fig. 3, 5, 6). Pelagic Unit 3 displays slight lateral thicknesses variations $(<0.1 \mathrm{~s}$ TWT), which results either from MTDs coming from the proto- Owen Ridge that still stood above the seafloor before the uplift, or from fanning related to a moderate tectonic activity (Fig. 5 a, b).

The transition between units 3 and 2 is marked by an increase of the sedimentation rates (from 15 to $54 \mathrm{~m} . \mathrm{Ma}^{-1}$ ) (Shipboard Scientific Party, 1989). Unit 2 is also marked by the appearance of submarine failures around $\sim 8.5 \mathrm{Ma}$ according to the nearby ODP Sites 721 and 731 (Fig. 2, 3, 5). The age of $\sim 8.5$ Ma corresponds to the age of the Foraminifera (Discoaster hamatus) immediately overlying the sedimentary hiatus (formed by the submarine failure) drilled at ODP Site 721. The configuration of submarine failures observed in the uppermost part of the pelagic sequence shows that the sediment failed and were transported in the direction of the Owen Basin (Fig. 3, 5), which indicates that the Owen Ridge was already uplifted at $\sim 8.5 \mathrm{Ma}$. The thickness of Unit 2 increases in the southernmost part of the Owen Ridge, where it displays a conspicuous fanning pattern (Fig. 6a), starting at $\sim 10 \mathrm{Ma}$, and ending at $8.5 \mathrm{Ma}$ (first pelagic layer over the MTD that seals the fanning). The sedimentary sequence at the top of the Owen Ridge is faulted throughout its entire thickness (Fig. 3b and 5a) by a dense network of faults very similar to what is observed on the Oman margin (Fig. 3a). These faults display very irregular offsets and do not root into the basement (Fig. 6a). We interpret these faults as the result of fluid circulation (i.e. polygonal faults as defined in Cartwight, 1994). The change of sedimentary setting induced by the uplift of the southern ridge and the margin sealed fluid circulation in most places. At the southern ridge, fluid circulation may have controlled the distribution of submarines failures (Rodriguez et al., 2012). 
Several folds are observed in the Indus abyssal plain at the eastern foot of the southern Owen Ridge, and south of the Beautemps-Beaupré Basin (Fig. 5c, 6). A sharp and vertical fault plane, interpreted as a fracture zone, crosscuts the eastern side of the Owen Ridge at depth (Fig. 6b, 6c; 7a). A system of fossil folds buried under Indus deposits and MTDs coming from the ridge is observed east of the southern ridge. The growth anticline displayed in Fig. $6 \mathrm{c}$ shows that compressive deformation is still active at the Owen Fracture Zone (Rodriguez et al., 2011). The series of folds observed south of the Beautemps-Beaupré Basin (Fig. 6d) display an isopach pattern at depth. The overlying deposits show angular unconformities indicating several discontinuities in episodes of folding. Unfortunately, the penetration of the nearby ODP Site 720 (location on Fig. 1) is too shallow to provide confident dating of the initiation of this compressive episode. These folds could correspond either to the Owen Ridge uplift at 8.5 Ma or to the emplacement of the Owen Fracture Zone between 3-6 Ma.

\subsection{Late Miocene deformation at the Central Owen Ridge and mass transport deposits}

Seismic profiles crossing the eastern side of the Central Owen Ridge document an angular unconformity within the Indus deep-sea fan (blue in Fig. 7). The angular unconformity becomes laterally concordant with the overlying sediments from the Indus fan. This key reflector is about $1 \mathrm{~s}$ TWT deep in the undeformed area, which roughly corresponds to a Late Miocene age according to the nearby DSDP Site 222. A sub-vertical fracture zone is identified at the eastern edge of the central ridge (Fig. 7a).

DSDP Site 223 is located west of the central segment of the Owen Ridge, where the Early Miocene unconformity was first determined (Shipboard Scientific Party, 1974; Whitmarsh, 1979). A second, younger unconformity is observed both in the Owen Basin (Fig. 5d) and at the top of the central Owen Ridge (Fig. 7), where it is underlined by MTDs composed of upper Miocene sediments (Fig. 3c) overlying diatoms-rich sediments dated at $10 \mathrm{Ma}$ (Shipboard Scientific Party, 1974). The reflector corresponding to the top of the MTDs is correlated with sediments at the top of the Central Owen Ridge. The overlying pelagic layer is $0.3 \mathrm{~s}$ (TWT) thick at the top of the central ridge, and devoid of MTDs. The thickness of $0.3 \mathrm{~s}$ (TWT) is the same as Unit 1 on the Southern Owen Ridge in areas undisturbed by submarine failures (Fig. 3). Assuming a pelagic sedimentation rate similar to the one 
estimated at the southern ridge (Bourget et al., 2013) implies a Late Miocene age of the unconformity ( $\sim 8 \mathrm{Ma}$ ), consistent with the MTDs drilled downslope at DSDP Site 223. A similar unconformity sealed by $0.3 \mathrm{~s}$ (TWT) of pelagic sediments is observed at the top of most of the bathymetric highs buried by the Indus fan and sediments from the Oman margin in the Owen Basin (Fig. 5 c). These observations suggest a regional tectonic deformation at the origin of the $\sim 8$ Ma-old unconformity and the uplift of the central Owen Ridge.

\section{Discussion}

\section{1. Age of uplift of the Owen Ridge and Late Miocene deformation in the Owen Basin}

The Late Miocene episode of deformation ( 8-9 Ma) described above contrasts with the 15-20 Ma age previously assessed for the major uplift of the Owen Ridge (Whitmarsh, 1979; Mountain and Prell, 1990). The main argument in favour of a 15-20 Ma-old uplift of the Owen Ridge was the 14-15 Maold mixed turbiditic-pelagic facies drilled at ODP Sites (Mountain and Prell, 1990). Because of its location on a turbiditic levee (Fig. 3), the mixed facies cannot be interpreted by itself as the first stage of the southern ridge uplift. During their deposition along turbiditic channels, turbiditic plumes frequently undergo flow-stripping or overspilling processes (Piper and Normark, 1983; Hiscott et al., 1997). These processes imply that the uppermost part of the turbiditic plume, composed of the thinner detritic particles, overflows throughout the channel axis, leading to the deposition of mixed turbiditicpelagic sequence on turbiditic levees similar to the one described at ODP Site 722 . The overlying pelagic deposits (Units 2-3) simply reflect a shift in the locus of turbidites deposition. Thick pelagic layers (>100 m-thick) are common features of the Indus deep-sea fan (DSDP Site 222, Shipboard Scientific Party, 1974; ODP Site 720, Shipboard Scientific Party, 1989), where the alternation of turbidites within pelagic sequences is controlled by avulsion processes, and not by seafloor uplift. The lysocline is currently at a depth of $\sim 4000 \mathrm{~m}$ in the area (Kolla et al., 1976) and its Miocene depth is unknown, making it difficult to discriminate whether fluctuations in the conditions of microfossils preservation throughout Unit 3 reflect the first stage of uplift of the Owen Ridge or oscillations in the lysocline depth. Slight lateral thickness variations ( $\sim 0.1 \mathrm{~s}$ (TWT)) of Unit 3 (10.4 to 14-15 Ma) may 
indicate nearby tectonic activity (Fig. $3 ; 5 \mathrm{a}, \mathrm{b}$ ), but with no major topographic building during the deposition of Unit 3.

The $~ 8.5-9$ Ma onset of major submarine failures is a striking feature of both the southern and the central Owen Ridges (Rodriguez et al., 2012; 2013a). The large expansion of the failure-related erosive surface over both ridge segments, together with the erosive surface observed at the top of buried reliefs in the Owen Basin and the synchronicity with the formation of anticlines along the Oman margin strongly suggest that they all relate to a common regional tectonic event.

The 8-9 Ma age of deformation in the Owen Basin fits with the estimated Tortonian age (7.2-11.6 Ma) of the post-rift uplift episode observed along the Dhofar margin in the Gulf of Aden (Platel and Roger, 1989; Lepvrier et al., 2002; Fournier et al., 2004; Petit et al., 2007; Gunnel et al., 2007; Bache et al., 2010). Several local processes have been invoked for the uplift episode in the Dhofar (Bache et al., 2010; Leroy et al., 2010), but the Late Miocene episode of deformation identified in the Owen Basin could better account for this uplift as rifted areas are prone to be reactivated by intra-plate deformation (e.g. Cloetingh et al., 2008). On the other hand, the reassessed age of deformation in the Owen Basin contrasts with the age of uplift of the Murray Ridge estimated at 20 Ma (Clift et al., 2001; Gaedicke et al., 2002). This discrepancy may reflect either the lack of good stratigraphic control of the deformation in the vicinity of the Murray Ridge, or a different tectonic episode. Recent ties with industrial drillings (Calvès, 2008) shows that the youngest turbidites tilted by the uplift of the Murray Ridge are actually 8-10 Myr-old.

\section{2. Uplift of the Owen Ridge and the Early-Middle Miocene India-Arabia boundary}

The fracture zone segments observed at the eastern edge of the Owen Ridge (Fig. 6b, 6c) likely correspond to the fossil India-Arabia plate-boundary in Early-Middle Miocene times, prior to the onset of the Owen Fracture Zone. The system of buried fold observed on Fig. 5c probably marks the deformation related to the Owen Ridge uplift. The fossil plate boundary must have been very weak to allow the $>2000 \mathrm{~m}$ uplift of the Owen Ridge. Based on free-air gravimetry and seismic profiles analysis, Weissel et al. (1992) showed that the uplift of the Owen Ridge may have occurred as a flexural response to either an extensional or a compressive event, making the tectonic interpretation of 
the ridge ambiguous. Vertical deformation within the oceanic lithosphere is mainly controlled by the lithospheric strength, which is a direct function of the thermal state - and therefore the age - of the lithosphere (Weissel et al., 1992). Consequently, even a slight change in the stress field can generate prominent seafloor uplift $(>1000 \mathrm{~m})$ of flexural origin in areas of strong rheological contrasts (i.e. the India-Arabia plate-boundary and the Oman margin).

The uplift of the Owen Ridge may be responsible for the transition from the Miocene plate boundary to the Owen Fracture Zone. The vertical offset along the fracture zone might have changed the stress field around it, leading to the formation of a nearby new transform segment while the initial one became extinct, in a way similar to what inferred for normal faults dynamics (Buck et al., 1993; Bonatti et al., 2005). In this framework, the 3-6 Ma-old Owen Fracture Zone (Fournier et al., 2008a, $2008 \mathrm{~b} ; 2011$ ) is a new transform segment located only 5-10 km from the previous segment (Fig. 6). Considering that the uplift started around 10.5 Ma, the early-middle Miocene boundary accommodated vertical motion during several million years prior to the onset of the Owen Fracture Zone. This structural reorganization of the India-Arabia plate-boundary did not involve any significant change in the direction of the India-Arabia relative motion, according to the kinematics reconstructions of Chamot-Rooke et al. (2009).

\section{3. Origin of the Late Miocene deformation in the Owen Basin}

The 15-20 Ma uplift of the Owen Ridge used to be related with the onset of seafloor spreading at the Sheba Ridge (Cochran, 1981; Mountain and Prell, 1990). The Late Miocene age of uplift of the Owen Ridge requires another tectonic trigger.

In the Arabian Sea, the magnetic anomalies observed over the Carlsberg (Somalia-India motion) and the Sheba ridges (Somalia-Arabia motion) documents a slow deceleration of seafloor spreading rates between 20 and $10 \mathrm{Ma}$, then followed by nearly constant spreading rates after 8-10 Ma (DeMets et al., 2005; Merkouriev and DeMets, 2006; Fournier at al., 2010). A two-phases growth of compressive folds is recognized in the Central Indian Ocean, the first and minor one being dated at $14-15 \mathrm{Ma}$ (Krishna et al., 2009), and the second, major one, at 8-9 Ma (Weissel et al., 1980; Wiens et al., 1985; Cochran et al., 1989; Bull and Scrutton, 1990, 1992; Chamot-Rooke et al., 1993; Delescluse et al., 
2008a; Bull et al., 2010). Age of the intraplate extension, counterpart of the intraplate compression, is also compatible with a beginning of widespread deformation within the Indo-Australian plate around $10 \mathrm{Ma}$ (Henstock et al., 2004). It suggests that the entire plate was subjected to a kinematic change around 8-10 Ma, affecting both the plate interior and its boundaries.

The origin of the kinematic change responsible for the Indo-Australian intraplate deformation is a matter of debate. Clark (2012) proposed a convergence of India with respect to Eurasia smoothly decreasing through time since the very beginning of the collision, as a result of the viscous resistance exerted by the lithospheric mantle in the collision zone. The latter does not explain the origin of the 810 Ma kinematic change. Molnar and Stock (2009) proposed that the growth of the Himalayas increased the gradient of gravitational potential energy, resulting in an increase in stress applied on the Indian plate and its boundaries. However, the Himalaya-Tibet reached its present-day altitude some 15 Ma, and probably earlier (Yuan et al., 2013). Late Miocene deformation at India's plate boundaries may have occurred once the stress induced by gravitational potential energy exceeded some threshold value. Onset of widespread deformation in the Indian Ocean may relate to strength loss of the oceanic lithosphere in relation with fault selective abandonment (Delescluse et al., 2008a) and further serpentinization (Delescluse and Chamot-Rooke, 2008b). Delescluse and Chamot-Rooke (2007) and Copley et al. (2010) alternatively proposed that the driving forces resulted from changes in the slabpull forces at Sunda subduction. Whatever the driver, the 8-9 Ma episode of deformation within IndoAustralian plate modified the kinematics at all surrounding plate's boundaries.

\section{4. Implications for the Indian monsoon and environmental changes}

The seafloor of the Owen Ridge was significantly uplifted at $\sim 8.5 \mathrm{Ma}$ above the lysocline, inducing the apparent dominance of G. bulloides since 8.5 Ma (Shipboard Scientific Party, 1989; Kroon et al., 1991) unrelated to monsoon intensification (Huang et al., 2007). The Late Miocene change in Foraminifera abundances therefore reflects a change in their conditions of preservation rather than a climatic change.

In absence of any monsoon intensification at $8.5 \mathrm{Ma}$, the origin of the coeval environmental change in the Siwalik sequence in Pakistan is enigmatic. This environmental change is characterized by a shift 
from the dominance of $\mathrm{C}_{3}$ to $\mathrm{C}_{4}$ plants in the vegetation $\left(\mathrm{C}_{3}\right.$ and $\mathrm{C}_{4}$ plants using a different photosynthesis pathway) (Quade et al., 1989; Cerling et al., 1997; Molnar, 2005). The estimated decrease in annual precipitation $(\sim 120 \mathrm{~mm})$, the increase in annual temperature $\left(+3^{\circ} \mathrm{C}\right)$, as well as the decrease in atmospheric $\mathrm{CO}_{2}$ (Cerling et al., 1997) at $~ 8-9$ Ma cannot account for the ecological transition alone (Nelson, 2006; Huang et al., 2007). Huang et al. (2007) propose that the ecological transition resulted from a large-scale hydrological change over Pakistan and he Himalayan foreland, but the origin of this hydrological change is unknown.

Tectonic processes involved in surface uplift act at a different time-scale and are less precisely dated than ecological and climatic changes, making any relationship based on synchronicity difficult to assess. However, the environmental change is coeval with several indicators of surface uplift in Pakistan that might have helped the environmental transition through Indus River avulsion (Fig. 8), which provides a likely origin for the hydrological change pointed out by Huang et al. (2007). Indeed, the Makran underwent a structural reorganization in Late Miocene while the frontal thrust migrated southward. Folds reaching altitudes of 1000-2000 m according to field works (McCall, 1997; Ellouz Zimmerman et al., 2007) triggered a huge submarine olistostrome ( 42 $\left.000 \mathrm{~km}^{3}\right)$ (Burg et al., 2008). The Kirthar, Sulaiman and Salt ranges also underwent complex structural reorganizations during the Late Miocene. These structural reorganizations favoured a complex episode of avulsion of the Indus River over more than $400 \mathrm{~km}$ (Waheed and Wells, 1990; 1992), which is at its present-day location since only $5 \mathrm{Ma}$ (Clift and Blusztajn, 2005). Surface uplift in Pakistan reduced monsoon precipitation coming from the ocean and increased aridity, without affecting the seasonality (consistently with environment reconstructions of Nelson, 2006). Surface uplift also explains the greater fraction of precipitation coming from continental sources in the Siwalik area, revealed by geochemical studies of Huang et al. (2007). The complex interplay between precipitation source changes (Huang et al., 2007) and Indus avulsion (Waheed and Wells, 1990, 1992) triggered by surface uplift over Pakistan induced successive fragmentations of habitats and the related ecological stresses that lead to the environmental change (Barry et al., 2002).

\section{Conclusions}


The Owen margin, basin and ridge have undergone a significant episode of deformation in the Late Miocene, leading to the uplift of the east Oman margin and the Owen Ridge. The best-dated deformation is the anticline structure on the Oman margin, bracketed between 8.2 and $8.8 \mathrm{Ma}$. This episode of deformation corresponds to the transition from the Early-Middle Miocene India-Arabia plate boundary to the Owen Fracture Zone. The Late Miocene episode of deformation at the IndiaArabia plate boundary is coeval with intraplate deformation in the Central Indian Ocean, suggesting a possible common cause.

The uplift of the Owen Ridge induced changes in the condition of preservation of Foraminifera, which confirms the previous assumption of Huang et al. (2007) that the apparent increase in $G$. Bulloides at $8.5 \mathrm{Ma}$ is not related to a climatic change. The monsoon might have already been strong at $10 \mathrm{Ma}$, then decreasing over the Arabian Sea until $\sim 5 \mathrm{Ma}$ (Clift et al., 2008; Prasanta and Sinha, 2010; Sakai et al., 2010). Proxies recording changes in summer monsoon intensity east of India, i.e. Chinese loess, abundances of N. dutertrei in South China Sea, windblown record in northeast Pacific (Molnar et al., 2010; Steinke et al., 2010), may reflect a shift in the trajectory of atmospheric eddies involved in the Indian monsoon that did not affect the western Indian Ocean. Contouritic drifts lay on the Late Miocene highs (Fig. 7), leading to the hypothesis that the uplift of the Owen Basin edges may also have changed the conditions of record of deep-sea current activity. The arising working hypothesis is that the general increase in carbonate preservation recorded in the Indian Ocean (Peterson et al., 1992) may be the result of the 8-9 Ma-old episode of seafloor uplift rather than the expression of a major climatic or deep-sea circulation change.

The questioning of the 8.5 Myrs monsoon intensification suggests that surface uplift in the Pakistan may be responsible for the coeval environmental change recorded in the Siwalik sequence. This environmental change influenced the evolution of mammals in the Late Miocene (Barry et al., 2002; Elton, 2008), including Sivapithecus, a likely ancestor of Pongo pygmae (Andrews and Cronin, 1982), who disappeared in Pakistan following the $8.5 \mathrm{Ma}$ ecological change (Begun, 2004).

\section{Acknowledgements}


We are grateful to Captain Rémi De Monteville, officers and crew members of the BHO BeautempsBeaupré, and to the GENAVIR team and the hydrographer D. Levieuge for their help in data acquisition. Processing of the Owen-2 dataset was carried out using the Geocluster 5000 software from CGGVeritas.We thank A. Rabaute who helped the organization of the Owen-2 cruise, J. Smith for scientific discussions, and P. Dubernet and N. Bacha for technical assistance. J. Bull, T. Henstock and an anonymous reviewer provided very constructive and careful comments that helped us to improve the manuscript and clarify our thoughts. This study was supported by SHOM, IFREMER, INSU-CNRS, and CEA (LRC Yves-Rocard).

\section{Figure captions}

Figure 1 : Bathymetric map of the Arabian Sea, with location of ODP and DSDP drilling sites. The multibeam bathymetric coverage is draped over SRTM-PLUS topography (Becker et al., 2009). Inset shows the regional tectonic setting of the India-Arabia plate boundary, and the position of the summer Inter-Tropical Convergence Zone (ITCZ). AOC : Aden-Owen-Carlsberg triple junction.

Figure 2 : Bathymetric maps of the central (a) and southern (b) portions of the Owen Basin, and location of the seismic lines. See Fig. 1 for location. The bathymetry shows the offset of the Owen Ridge by the Owen Fracture Zone (OFZ). DSDP and ODP Sites are shown by red stars.

Figure 3 : Seismic profiles crossing a) the Oman continental margin, b) the Southern Owen Ridge, c) the Central Owen Ridge (see Fig. 2 for location). Insets show close-views of the seismic profiles in the area of deep-sea drilling (ODP and DSDP) locations. The stratigraphic framework is summarized on the lower left hand corner. Profile a) displays a major anticline structure affecting chalk-rich turbiditic deposits that is overlapped by a 8 Ma-old contouritic drift, composed of pelagic ooze with inserted MTDs. Older events, including an upper-Eocene unconformity, and the obduction of Masirah Ophiolites, are not discussed in this study. Profile b) shows a W-E seismic profile crossing the Southern Owen Ridge at the location of ODP Site 722. The basement, drilled at DSDP Site 224, consists of 50-55 Ma-old basaltic lamprophyres. A major unconformity is observed on the western side of the ridge, where early miocene turbiditic deposits (Unit 4) onlap oligocene deposits drilled at 
DSDP site 224. Unit 3 corresponds to a pelagic layer and ends at $10.4 \mathrm{Ma}$. The overlying Unit 2 is

composed of radiolarian rich pelagic chalk and ends at 8.2 Ma. Unit 1 is composed of pelagic ooze and chalk, and dissected by landslide failures. c) shows an W-E seismic profile crossing the Central Owen Ridge. A major unconformity, corresponding to a hiatus of 6 Myr, has been drilled at DSDP Site 223, together with Late Miocene mass transport deposits. The overlying cover is mainly composed of pelagic chalk and ooze, with a detrital component in the Owen Basin. Late Miocene breccias, correlated with an unconformity on the central ridge, have been drilled at DSDP Site 223.

Figure 4 : Seismic profile crossing the Oman margin, showing a major anticline affecting Miocene sediments. See Fig. 2b (top left hand corner) for location, and Fig. 3 for stratigraphic legend.

Figure $5:$ a) and b) Seismic profiles crossing the top of the Owen Ridge, highlighting the fanning pattern of early Miocene turbidites. c) Seismic profile crossing the eastern foot of the Southern Owen Ridge, showing a buried system of folds corresponding to the syn-uplift deformation. d) Seismic profile crossing partly buried reliefs in the middle of the Owen Basin. It displays an unconformity draped by $0.3 \mathrm{~s}$ TWT of pelagic sediments, similar to the Late Miocene unconformity observed on the Central Owen Ridge. See Fig. 2 for profiles location.

Figure 6 : Seismic profiles crossing the Southern Owen Ridge. Profile a) shows a N-S section that displays the Late Miocene fanning marking the uplift of the Owen Ridge. A dense network of faults, with irregular offsets, affects Unit 1 to 4 , and may result from fluid escapes. Profile b) shows a transverse section of the southernmost extremity of the southern ridge. It shows that the ridge is formed by folded Indus sediments, crosscut to the east by an fossil vertical fault, interpreted as a fracture zone corresponding to the India-Arabia plate boundary. The present-day Owen Fracture Zone is observed on the western side of the ridge, where it is associated with the Beautemps-Beaupré basin. Profile c) shows a fracture zone at the eastern foot of the southern ridge, and compressive deformation in the overlying sediments. Profile d) shows a series of folds located south of the Beautemps-Beaupré Basin. 
See Fig. 2 for location and Fig. 3 for stratigraphic legend.

Figure 7 : Seismic profiles crossing the eastern side of the Central Owen Ridge. Profile a) shows an angular unconformity sealed by Late Miocene turbidites according to the nearby DSDP Site 222 . fracture zone is observed at the eastern foot of the ridge, the present-day active boundary being localized at the mid-slope of the ridge. Profile b) shows the Late Miocene angular unconformity formed during the uplift of the Owen Ridge. See fig. $2 b$ for location and fig. 3 for stratigraphic legend.

Figure 8 : Sketches of the geological history of the India-Arabia plate boundary, and the Owen Basin since the Middle Miocene. At $\sim 10 \mathrm{Ma}$, the India-Arabia plate boundary was located close to the Owen Ridge, which was mostly buried under Indus turbiditic system, excepted a few highs standing above the seafloor. Pakistan was flooded by the Indus delta (Ellouz-Zimmerman et al., 2007). Around 8.5 Ma, the Owen Ridge and the Oman margin uplifted, inducing a better preservation of pelagic foraminifera on their top. This event is coeval with general plate reorganization recognized overall the Indian Ocean. The Makran Subduction Zone underwent a major structural reorganization during Tortonian (McCall, 1997), marked by olistostromes (Burg et al., 2008) and a geographic isolation of paleontological species with regards to the area east of the Kirthar Ranges (Ellouz-Zimmerman et al., 2007). The precise location of the frontal thrust in Tortonian is currently unknown. Since 3-6 Ma, the Miocene India-Arabia plate boundary jumped to the Owen Fracture Zone emplaced with large stepover basins along strike. The Oman margin subsided down below the sea level. The Indus river is at its present-day location since $\sim 5-6 \mathrm{Ma}$ (Clift and Blusztajn, 2005).

\section{References}

An, Z., Kutzbach, J.E., Prell, W.L., Porter, S.C., 2001.Evolution of Asian monsoons and phased uplift of the Himalaya-Tibetan plateau since Late Miocene times. Nature 411, 62-66.

Andrews, P., and Cronin, J. E., 1982. The relationships of Sivapithecus and Ramapithecus and the evolution of the orang-utan. Nature 297, 541-546.

Bache, F., Leroy, S., Baurion, C., Robinet, J., Gorini, C., Lucazeau, F., Razin, P., d'Acremont, E., Al- 
Toubi, K., 2010. Post-rift uplift of the Dhofar margin (Gulf of Aden). Terra nova 23, 11-18, DOI: 10.1111/j.1365-3121.2010.00975.x, 2010.

Barry, J., Morgan, M. E., Flynn, L. J., Pilbeam, D., Behrensmeyer, A. K., Raza, S. M., Khan, I. A., Bagdley, C., Hicks, J., Kelley, J., 2002. Faunal and environmental change in the late Miocene Siwaliks of northern Pakistan. Paleobiology 28, 1-71, http://dx.doi.org/10.1666/00948373(2002)28[1:FAECIT]2.0.CO;2

Brackenridge, R. E., Hernandez-Molina, F. J., Stow, D. A. V., Llave, E, 2013. A Pliocene mixed contourite-turbidite system offshore the Algarve Margin, Gulf of Cadiz: Seismic response, margin evolution and reservoir implications. Mar. Pet. Geol. 46, 36-50, http://dx.doi.org/10.1016/j.marpetgeo.2013.05.015

Becker, J. J., Sandwell, D. T., Smith, W. H. F., Braud, J, Blinder, B., Depner, J., Fabre, D., Factor, J., Ingalls, S., Kim, S-H., Ladner, R., Marks, K., Nelson, S., Pharaoh, A., Trimmer, R., Von Rosenberg, J., Wallace, G., Weatherall, P., 2009. Global bathymetry and elevation data at 30 arc second resolution : SRTM30 PLUS. Marine Geodesy 32, 355-371, doi: $10.1080 / 01490410903297766$

Begun, D. R., 2004. Sivapithecus is east and Dryopithecus is west, and never the twain shall meet. Anthropological science 113, 53-64.

Bernard, A. and Munschy, M., 2000. Le bassin des Mascareignes et le bassin de Laxmi (océan Indien occidental) se sont-ils formés à l'axe d'un même centre d'expansion ? C. R. Acad. Sci. Paris, 330, $777-783$

Bonatti, E., Ligi, M., Gasperini, L., Peyve, A., Raznitsin, Y., Chen, Y. J., 1994. Transform migration and vertical tectonics at the Romanche fracture zone, equatorial Atlantic. J. Geophys. Res. 99, 21779-802.

Bonatti, E., Brunelli, D., Buck, W. R., Cipriani, A., Fabretti, P., Ferrante, V., Gasperini, L., Ligi, M., 2005. Flexural uplift of a lithospheric slab near the Vema transform (Central Atlantic) : timing and mechanisms. Earth. Planet. Sci. Lett. 240, 642-655.

Bourget, J., Zaragosi, S., Rodriguez, M., Fournier, M., Garlan, T., Chamot-Rooke, N., 2013. Late Quaternary megaturbidites of the Indus Fan : origin and stratigraphic significance. Mar. Geol. 336, 
Buck., W. R., 1993. Effect of lithospheric thickness on the formation of high- and low-angle normal faults. Geology 21, 933-936.

Bull, J. M., and Scrutton, R. A., 1990. Fault reactivation in the central Indian Ocean and the rheology of oceanic lithosphere. Nature 344, 855-858.

Bull, J. M., and Scrutton, R. A., 1992. Seismic reflection images of intraplate deformation, central Indian Ocean, and their tectonic significance. J. Geol. Soc. London 149, 955-966.

Bull, J. M., DeMets, C., Krishna, K. S., Sanderson, D. J., Merkouriev, S., 2010. Reconciling plate kinematic and seismic estimates of lithospheric convergence in the central Indian Ocean. Geology 38, 307-310, doi: 10.1130/G30521.1

Burg, J.P., Bernoulli, D., Smit, J., Dolati, A., Bahroudi, A., 2008. A giant catastrophic mud-and-debris flow in the Miocene Makran. Terra Nova 20, 188-193, doi: 10.1111/j.1365-3121.2008.00804.x

Calvès, G., 2008.Tectonostratigraphic and climatic record of the NE Arabian Sea, Ph.D. thesis, 305 pp., Univ. of Aberdeen, Aberdeen U. K.

Cartwright, J. A., 1994. Episodic basin-wide fluid expulsion from geo-pressured shale sequences in the North Sea Basin. Geology 22, 447-450.

Cerling, T.E., Harris, J.M., MacFadden, B.J., Leakey, M.G., Quade, J., Eisenmann, V.,Ehleringer, J.R., 1997.Global vegetation change through the Miocene/Pliocene boundary. Nature 389, 153-158.

Chamot-Rooke, N., Jestin, F., DeVoogd, B., 1993. Intraplate shortening in the central Indian-ocean determined from a 2100-km-long north-south deep seismic-reflection profile. Geology 21(11), $1043-1046$.

Cochran, J. R., 1981. The Gulf of Aden: structure and evolution of a young ocean basin and continental margin. J. Geophys. Res. 86, 263-287.

Cochran, J. R., et al., 1989. Intraplate deformation and Bengal fan sedimentation: background and objectives. Proc. Ocean Drill. Program Initial Rep. 116, 3-11.

Clark, M. K., 2012. Continental collision slowing due to viscous mantle lithosphere rather than topography, Nature 483, 74-77, doi:10.1038/nature10848

Clift, P. D., Shimizu, N., Layne, G. D., Blusztain, J. S., Gaedicke, C., Schluter, H.-U., Clark,M. K., 
Amjad, S., 2001.Development of the Indus Fan and its significance for the erosional history of the Western Himalaya and Karakoram.Geol. Soc. Am. Bull. 113, 1039-1051.

Clift, P. D., Gaedicke, C., 2002. Accelerated mass flux to the Arabian Sea during the middle to late Miocene. Geology 30, 207-210, doi:10.1130/0091-13(2002)030<0207:AMFTTA>2.0.CO;2Clift, P. D., 2006. Controls on the erosion of Cenozoic Asia and the flux of clastic sediment to the ocean. Earth Planet. Sci. Lett. 241, 571-580.

Clift, P. D., Hodges, K. V., Heslop, D., Hannigan, R., Van Long, H., Calvès, G., 2008. Correlation of Himalayan exhumation rates and Asian monsoon intensity. Nat. Geosci. 1, 875-880, doi:10.1038/ngeo351

Clift, P. D., 2010. Enhanced global continental erosion and exhumation driven by Oligo-Miocene climate change. Geophys. Res. Lett. 37, L09402, doi:10.1029/2010GL043067

Cloething, S., Beekman, F., Ziegler, P. A., van Wees, J-D., Sokoutis, D., 2008. Post-rift compressional reactivation potential of passive margins and extensional basins. Geol. Soc. London Spec. Publ. $306,27-70$.

Copley, A., Avouac, J-P., Royer, J-Y., 2010. India-Asia collision and the Cenozoic slowdown of the Indian plate: implications for the forces driving plate motions. J. Geophys. Res. 115, B03410, doi:10.1029/2009JB006634

Delescluse, M., and Chamot-Rooke, N., 2007. Instantaneous deformation and kinematics of the IndiaAustralia Plate. Geophys. J. Int. 168, 818-842, doi: 10.1111/j.1365-246X.2006.03181.x

Delescluse, M., Montési, L. G. J., Chamot-Rooke, N., 2008a. Fault reactivation and selective abandonment in the oceanic lithosphere. Geophys. Res. Lett. 35, L16312, doi:10.1029/2008GL035066.

Delescluse, M., and Chamot-Rooke, N., 2008b. Serpentinization pulse in the actively deforming Central Indian Basin. Earth Planet. Sci. Lett., v. 276, p. 140-151.

DeMets, C., Gordon, R., Royer, J-Y., 2005. Motion between the Indian, Capricorn and Somalian plates since $20 \mathrm{Ma}$ : implications for the timing and magnitude of distributed lithospheric deformation in the equatorial Indian Ocean. Geophys. J. Int. 161, 445-468, doi: 10.1111/j.1365246X.2005.02598.x 
DeMets C., Gordon, R. G., Argus, D.F., 2010.Geologically current plate motions. Geophys. J. Int. 181, 1-80, doi: 10.1111/j.1365-246X.2009.04491.x.

Dupont-Nivet, G., Hoorn, C., Konert, M., 2008. Tibetan uplift prior to the Eocene-Oligocene climate transition : Evidence from pollen analysis of the Xining Basin. Geology 36, 987-990, doi: $10.1130 / \mathrm{G} 25063 \mathrm{~A} .1$

Dyment, J., 1998. Evolution of the Carlsberg Ridge between 60 and 45 Ma: Ridge propagation, spreading asymmetry, and the Deccan-Reunion hotspot. J. Geophys. Res. 103, 24067-24084 DOI: $10.1029 / 98 J B 01759$.

Edwards, R.A., Minshull, T. A., White, R. S., 2000. Extension across the Indian-Arabian plate boundary: the Murray Ridge. Geophys. J. Int. 142, 461-477.

Edwards, R. A., Minshull, T. A., Flueh, E. R., Kopp, C., 2008. Dalrymple Trough: An active obliqueslip ocean-continent boundary in the northwest Indian Ocean. Earth Planet. Sci. Lett. 272, 437-445.

Ellouz Zimmermann, N., Deville, E., Müller, C., Lallemant, S., Subhani, A. B., Tabreez, A. R., 2007. Impact of sedimentation on convergent margin tectonics : example of the Makran Accretionary prism (Pakistan). Thrust Belts and Foreland Basins: From Fold Kinematics to Hydrocarbon Systems, edited by O. L. Lacombe et al., pp. 327-350, Springer, Berlin.

Ellouz Zimmermann, N. et al., 2007. Offshore frontal part of the Makranaccretionary prism (Pakistan) the Chamak Survey. Thrust Belts and Foreland Basins: From Fold Kinematics to Hydrocarbon Systems, edited by O. L. Lacombe et al., pp. 349-364, Springer, Berlin.

Faugères, J.C., Stow, D.A.V., Imbert, P., Viana, A., 1999.Seismic features diagnostic of contourite drifts. Mar. Geol. 162, 1-38.

Fournier, M., Bellahsen, N., Fabbri, O., Gunnell, Y., 2004. Oblique rifting and segmentation of the NE Gulf of Aden passive margin. Geochem. Geophys. Geosyst. 5, Q11005, doi:10.1029/2004GC000731

Fournier, M., Chamot-Rooke N., Petit C., Fabbri O., Huchon P., Maillot B., Lepvrier C., 2008a. Insitu evidence for dextral active motion at the Arabia-India plate boundary. Nat. Geosci. 1, 54-58, doi:10.1038/ngeo.2007.24.

Fournier, M., Petit C., Chamot-Rooke N., Fabbri O., Huchon P., Maillot B., Lepvrier, C., 2008b) Do 
ridge-ridge-fault triple junctions exist on Earth? Evidence from the Aden-Owen-Carlsberg junction in the NW Indian Ocean. Basin Research 20, 575-590.doi: 10.1111/j.1365-2117.2008.00356.x

Fournier, M., Chamot-Rooke, N., Petit, C., Huchon, P., Al-Kathiri, A., Audin, L., Beslier, M.-O., d'Acremont, E., Fabbri, O., Fleury, J.-M., Khanbari, K., Lepvrier, C., Leroy, S., Maillot B., Merkouriev, S., 2010.Arabia-Somalia plate kinematics, evolution of the Aden-Owen-Carlsberg triple junction, and opening of the Gulf of Aden. J. Geophys. Res. 115, B04102, doi:10.1029/2008JB006257

Fournier, M., Chamot-Rooke N., Rodriguez, M., Huchon, P., Petit, C., Beslier, M.-O., Zaragosi S., 2011. Owen Fracture Zone: the Arabia-India plate boundary unveiled. Earth Planet. Sci. Lett. 302, 247-252, doi:10.1016/j.eps1.2010.12.027.

Gaedicke, C., Prexl, A., Schlüter, H.U., Roeser, H., Clift, P., 2002. Seismic stratigraphy and correlation of major regional unconformities in the northern Arabia Sea.The Tectonic and Climatic Evolution of the Arabian Sea Region, edited by Clift, P. D., Kroon, D., Gaedicke, C., \& Craig, J., Geol. Soc. Spec. Publ. 195, 25-36.

Gunnell, Y., Carter, A. Petit, C., Fournier, M., 2007. Post-rift seaward downwarping at passive margins: new insights from southern Oman using stratigraphy to constrain apatite fission-track and (U-Th)/He dating, Geology 35, 647-650, doi:10.1130/G23639A.1

Harris, N. B. W., 2006, The elevation of the Tibetan Plateau and its impact on the monsoon. Palaeogeography Palaeoclimatology Palaeoecology 241, 4-15.

Harrison, T.M., Copeland, P., Kidd, W.S.F., Yin, A., 1992. Raising Tibet. Science 255, 1663-1670.

Henstock, T. J.,Minshull, T. A., 2004. Localized rifting at Chagos bank in the India-Capricorn plate boundary zone. Geology 32, 237-240.

Hiscott, R. N., Pickering, K. T.,Bouma, A. H., Hand, B. M., Kneller, B. C.,Postma, G.,Soh, W.,1997. Basin-Floor Fans in the North Sea: Sequence Stratigraphic Models vs. Sedimentary Facies: Discussion. AAPG bull. 81, 662-665

Huang, Y., Clemens, S. C., Liu, W., Wang, L., Prell, W. L., 2007. Large-scale hydrological change drove the Late Miocene C4 plant expansion in the Himalayan foreland and Arabian Peninsula. Geology 35, 531-534. 
Kolla, V., Bé, A. W. H., Biscaye, P. E., 1976. Calcium Carbonate distribution in the surface sediments of the Indian Ocean. J. Geophys. Res. 81, 2605-2616.

Krishna, K. S., Bull, J. M., Scrutton, R. A., 2009. Early (pre-8 Ma) fault activity and temporal strain accumulation in the central Indian Ocean. Geology 37, 227-230, doi: 10.1130/G25265A.1

Kroon, D., Steens, T.,Troelstra, S.R., 1991. Onset of monsoonal related upwelling in the western Arabian Sea as revealed by planktonic foraminifers. In Prell, W.L., Niitsuma, N., et al., Proceedings of the Ocean Drilling Project, Sci. Results, 117, 257- 263 College Station, Texas (Ocean Drilling Program).

Lepvrier, C., Fournier, M. Bérard, T. Roger, J., 2002. Cenozoic extension in coastal Dhofar (southern Oman): Implications on the oblique rifting of the gulf of Aden. Tectonophysics 357, 279-293.

Leroy, S. et al., 2010. From rifting to oceanic spreading in the Gulf of Aden: a synthesis. Arab.J.Geosci. doi 10.1007/s12517-011-0475-4

Marches E., Mulder T., Gonthier E., Hanquiez V., Cremer M., Garlan T., Lecroart P., 2010. Perched lobes formation induced by contourite construction in the Gulf of Cadiz: Interactions between gravity processes and contour currents (Algarve Margin, South Portugal), Sedimentary Geology $229,81-94$.

McCall, G.J.H., 1997. The geotectonic history of the Makran and adjacent areas of southern Iran. J. Asian Earth Sci., 15, 517-531.

Mercuriev, S., DeMets, C., 2006.Constraints on Indian plate motion since 20 Ma from dense Russian magnetic data: Implications for Indian plate dynamics. Geochem. Geophys.Geosyst. 7, Q02002, doi:10.1029/2005GC001079.

Molnar, P., England, P., 1990. Late Cenozoic uplift of mountain ranges and global climatic change: chicken or egg? Nature 346, 29-34.

Molnar, P., England, P., Martinod, J., 1993. Mantle dynamics, uplift of the Tibetan Plateau, and the Indian monsoon. Rev. Geophys. 31, 357-396.

Molnar, P., 2005. Mio-Pliocene Growth of the Tibetan Plateau and Evolution of East Asian Climate. Palaeontologia Electronica 8, 1-23. 
Molnar, P., Stock, J., 2009. Slowing of India's convergence with Eurasia since $20 \mathrm{Ma}$ and its implications for Tibetan mantle dynamics. Tectonics, 28, TC3001, doi:10.1029/2008TC002271

Molnar, P., Boos, W. R., Battisti, D. S., 2010. Orographic controls on climate and paleoclimate of Asia: thermal and mechanical role of the Tibetan Plateau. Annu. Rev. Earth Planet. Sci. 38, 77-102.

Mountain, G. S.,Prell, W.L., 1990.A multiphase plate tectonic history of the southeast continental margin of Oman. The Geology and Tectonics of the Oman Region, edited by Robertson, A. H. F., Searle, M. P. and Ries, A. C., Geol. Soc. Spec. Publ., 49, 725-743.

Nelson, S., 2006. Isotopic reconstructions of habitat change surrounding the extinction of Sivapithecus, a Miocene hominoid, in the Siwalik Group of Pakistan. Paleaogeo., Paleaoclim., Palaeoeco. 243, 204-222.

Peterson, L. C., Murray, D. W., Ehrmann, W. U., Hempel, P., 1992.Cenozoic carbonate accumulation and compensation depth changes in the Indian Ocean. In Synthesis of results from scientific drilling in the Indian Ocean, ed. RA Duncan, DK., Rea, R. B. Kidd, U. von Rad, J. K., Weissel, Geophys. Monogr. 70, 311-333. Am. Geophys. Union, Washington, D. C.

Petit, C., Fournier, M., Gunnell, Y., 2007.Tectonic and climatic controls on rift escarpments: Erosion and flexural rebound of the Dhofar passive margin (Gulf ofAden, Oman), J. Geophys. Res. 112, B03406, doi:10.1029/2006JB004554

Piper, D. J. W., Normark, W. R., 1983.Turbidite depositional patterns and flow characteristics, Navy Submarine Fan, California Borderland. Sedimentology 30, 681-694.DOI: 10.1111/j.13653091.1983.tb00702.x

Platel, J.P., Roger, J., 1989. Evolution géodynamique du Dhofar (Sultanat d'Oman) pendant le Crétacé et le Tertiaire en relation avec l'ouverture du golfe d'Aden, Bull. Soc. Géol. France 2, 253-263.

Prasanta, S., Sinha, R., 2010.Evolution of the Indian summer monsoon: synthesis of continental records. From: Clift, P. D., Tada, R. \& Zheng, H. (eds) Monsoon Evolution and Tectonics-Climate Linkage in Asia. Geological Soc. London, Spec. Publ., 342, 153-183.

Quade, J., Cerling, T.E., Bowman, J.R., 1989. Development of Asian monsoon revealed by marked ecological shift during the latest Miocene in northern Pakistan. Nature 342, 163-166. 
Qayyum, M., Lawrence, R. D., Niem, A. R., 1997. Discovery of the palaeo-Indus delta-fan complex. Journal of the Geological Society 154, 753-756, doi:10.1144/gsjgs.154.5.0753

Rodriguez, M., Fournier, M., Chamot-Rooke, N., Huchon, P., Bourget, J., Sorbier, M., Zaragosi, S., Rabaute, A., 2011.Neotectonics of the Owen Fracture Zone (NW Indian Ocean): structural evolution of an oceanic strike-slip plate boundary. Geochem., Geophys., Geosyst. 12, doi:10.1029/2011GC003731.

Rodriguez, M., Fournier, M., Chamot-Rooke, N., Huchon, P., Zaragosi, S., Rabaute, A., 2012. Mass wasting processes along the Owen Ridge (NW Indian Ocean). Mar. Geol. 326-328, 80-100, doi: 10.1016/j.margeo.2012.08.008

Rodriguez, M., Chamot-Rooke, N., Hébert, H., Fournier, M., Huchon, P. 2013. Owen Ridge deepwater submarine landslides: Implications for tsunami hazard along the Oman coast, NHESS, 13, $417-424$.

Rodriguez, M., Chamot-Rooke, N., Fournier, M., Huchon, P., Delescluse, M. 2013. Mode of opening of an oceanic pull-apart: The $20^{\circ} \mathrm{N}$ Basin along the Owen Fracture Zone (NW Indian Ocean), Tectonics 32, 1-15, doi:10.1002/tect.20083.

Rowley, D. B., Currie, B. S., 2006. Palaeo-altimetry of the late Eocene to Miocene Lunpola basin, central Tibet. Nature 439, 677-681.

Royer, J. Y., Chaubey, A. K., Dyment, J., Bhattacharya, G. C., Srinivas, K., Yateesh, V., Ramprasad,T., 2002.Paelogene plate tectonic evolution of the Arabian and Eastern Somali basins.in The Tectonic and Climatic Evolution of the Arabian Sea Region, edited by P. D. Clift et al., Geol. Soc. Spec. Publ., 195, 7-23Shipboard Scientific Party 1989, Site 731, Proc. Ocean. Drill. Program Initial Rep., 117, 585-652.

Shipboard Scientific Party, 1974, Site 222, In R.B. Whitmarsh, O.E. Weser, and D.A. Ross, DSDP Init. Repts, 23, doi:10.2973/dsdp.proc.23.106.

Sakai, T., Saneyoshi, M., Sawada, Y., Nakatsukasa, M., Mbua, E., Ishida, H., 2010. Climate shift recorded at around $10 \mathrm{Ma}$ in Miocene succession of Samburu Hills, northern Kenya Rift, and its significance. From: Clift, P. D., Tada, R. \&Zheng, H. (eds) Monsoon Evolution and TectonicsClimate Linkage in Asia. Geol. Soc., London, Spec. Publ. 342,109-127, doi:10.1144/SP342.9 
Smit, J., Burg, J-P., Dolati, a., Sokoutis, D., 2010. Effects of mass waste events on thrust wedges: Analogue experiments and application to the Makran accretionary wedge. Tectonics 29, TC3003, doi:10.1029/2009TC002526.

Spicer, R. A., Harris, N. B. W., Widdowson, M., Herman, A. B., Guo, S., Valdes, P.J., Wolfe, J. A., and Kelley, S. P., 2003, Constant elevation of southern Tibet over the past 15 million years. Nature $421,622-624$.

Steinke, S., Groeneveld, J., Johnstone, H., and Rendle-Bühring, R., 2010. East Asian summer monsoon weakening after 7.5 Ma: Evidence from combined planktonic foraminifera $\mathrm{Mg} / \mathrm{Ca}$ and $\delta 180$ (ODP Site 1146; northern South China Sea). Palaeogeography, Palaeoclimatology, Palaeoecology 289, 33-43.

Sun, X., and Wang, P., 2005. How old is the Asian monsoon system? Palaeobotanical records from China. Palaeogeography, Palaeoclimatology, Palaeoecology 222, 181-222.

Waheed, A., Wells, N. A., 1990. Changes in paleocurrents during the development of an obliquely convergent plate boundary (Sulaiman fold-belt, southwestern Himalayas, west-central Pakistan). Sedimentary Geology 67, 237-261.

Waheed, A., Wells, N. A., 1992. Fluvial history of late Cenozoic molasse, Sulaiman range, Pakistan. Geol. Bull. Univ. Peshawar 25, 1-15.

Wang, P., Steven Clemens, S., Beaufort, L., Braconnot, P., Ganssene, G., Jiana, Z., Kershawf, P., Sarntheing, M., 2005. Evolution and variability of the Asian monsoon system: state of the art and outstanding issues. Quaternary Sci. Rev. 24, 595-629.

Wang, E., Kirby, E., Furlong, K. P., van Soest, M., Xu, G., Shi, X., Kamp, P. J. J., Hodges, K. V., 2012. Two-phase growth of high topography in eastern Tibet during Cenozoic. Nat. Geosci. 5, 640-645, doi:10.1038/ngeo1538

Weissel, J. K., Anderson, R. N., Geller, C. A., 1980. Deformation of the Indo-Australian plate. Nature 287, 284-291.

Weissel, J.K., Childers, V.A., Karner, G.D., 1992. Extensional and Compressional Deformationof the Lithosphere in the Light of ODP Drilling in the Indian Ocean.Synthesisof Results from Scientific Drilling in the Indian Ocean. : Geophysical Monograph70, American Geophysical Union. 
723 Whitmarsh, R.B., 1979. The Owen Basin off the south-east margin of Arabia and the evolution of the 724 Owen Fracture Zone. Geophysical Journal of the Royal Astronomical Society 58, 441-470.

725 Wiens, D. A., Demets, C., Gordon, R. G., Stein, S., Argus, D., Engeln, J. F., Lundgren, P., Quible, D., 726 Stein, C.,Weinstein, S., Woods,D. F., 1985. A diffuse plate boundary model for Indian ocean 727 tectonics. Geophys. Res.Lett. 12, 429-432.

728 Yuan, D-Y., et al., 2013. The growth of northeastern Tibet and its relevance to large-scale continental 729 geodynamics: a review of recent studies. Tectonics 32, 1-13, doi:10.1002/tect.20081 


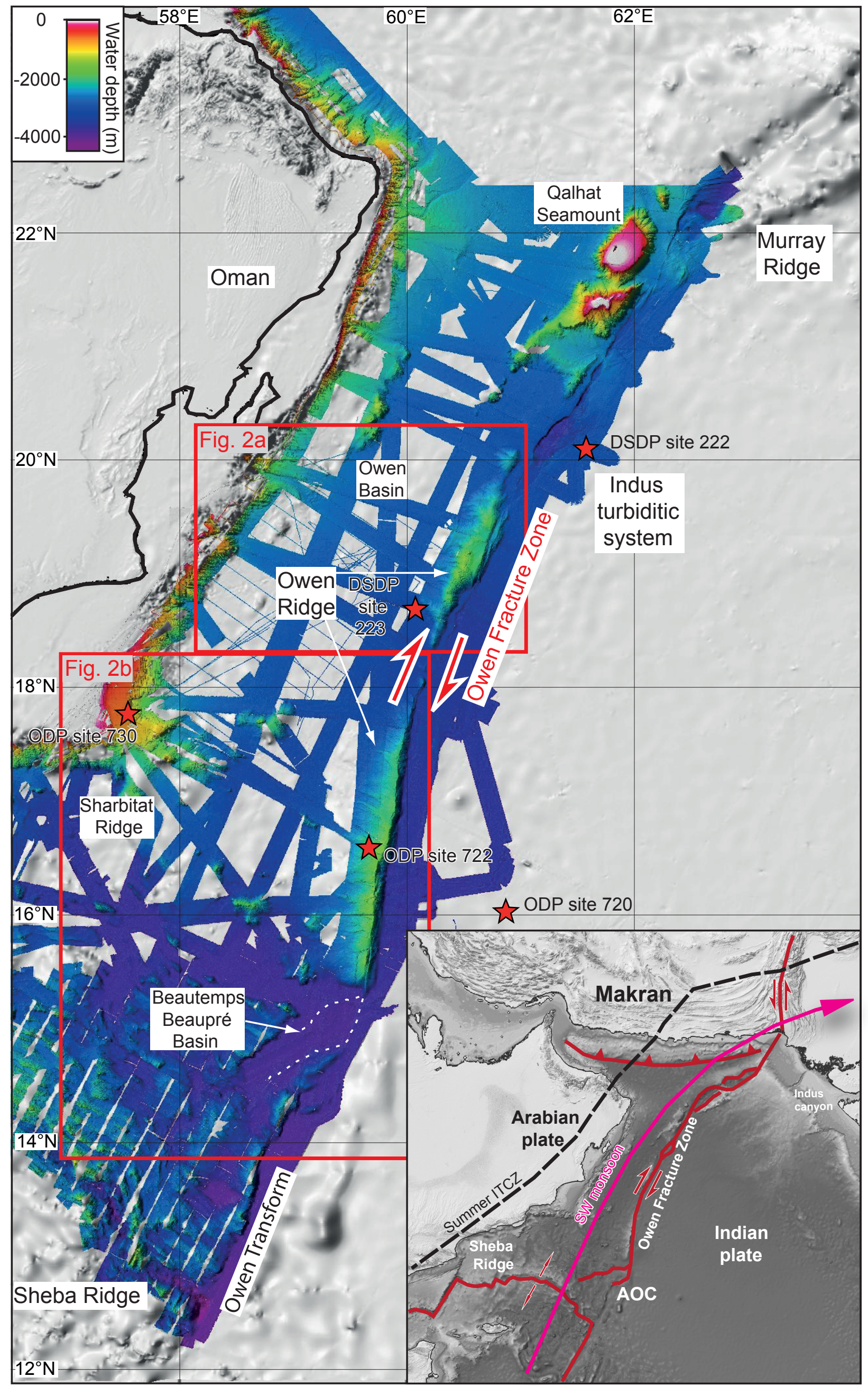



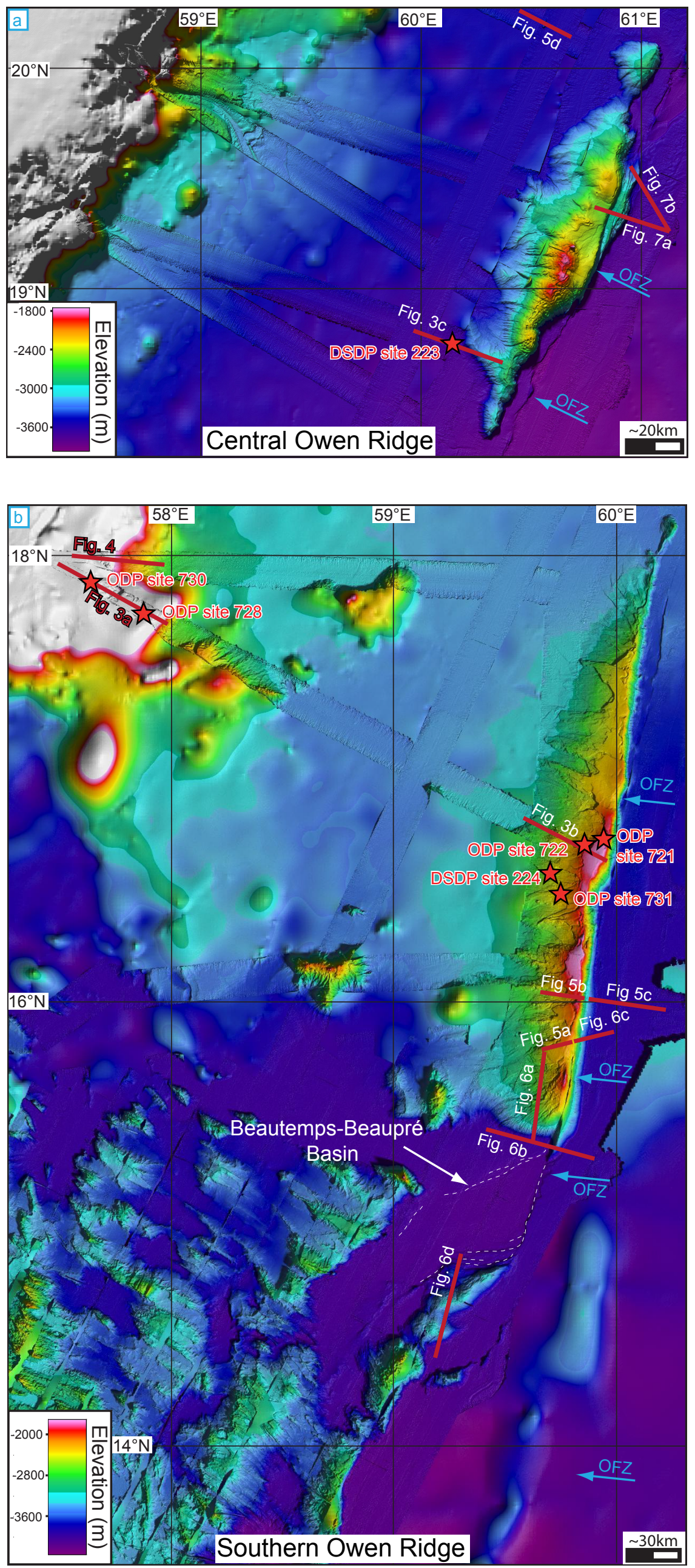

Figure 2 

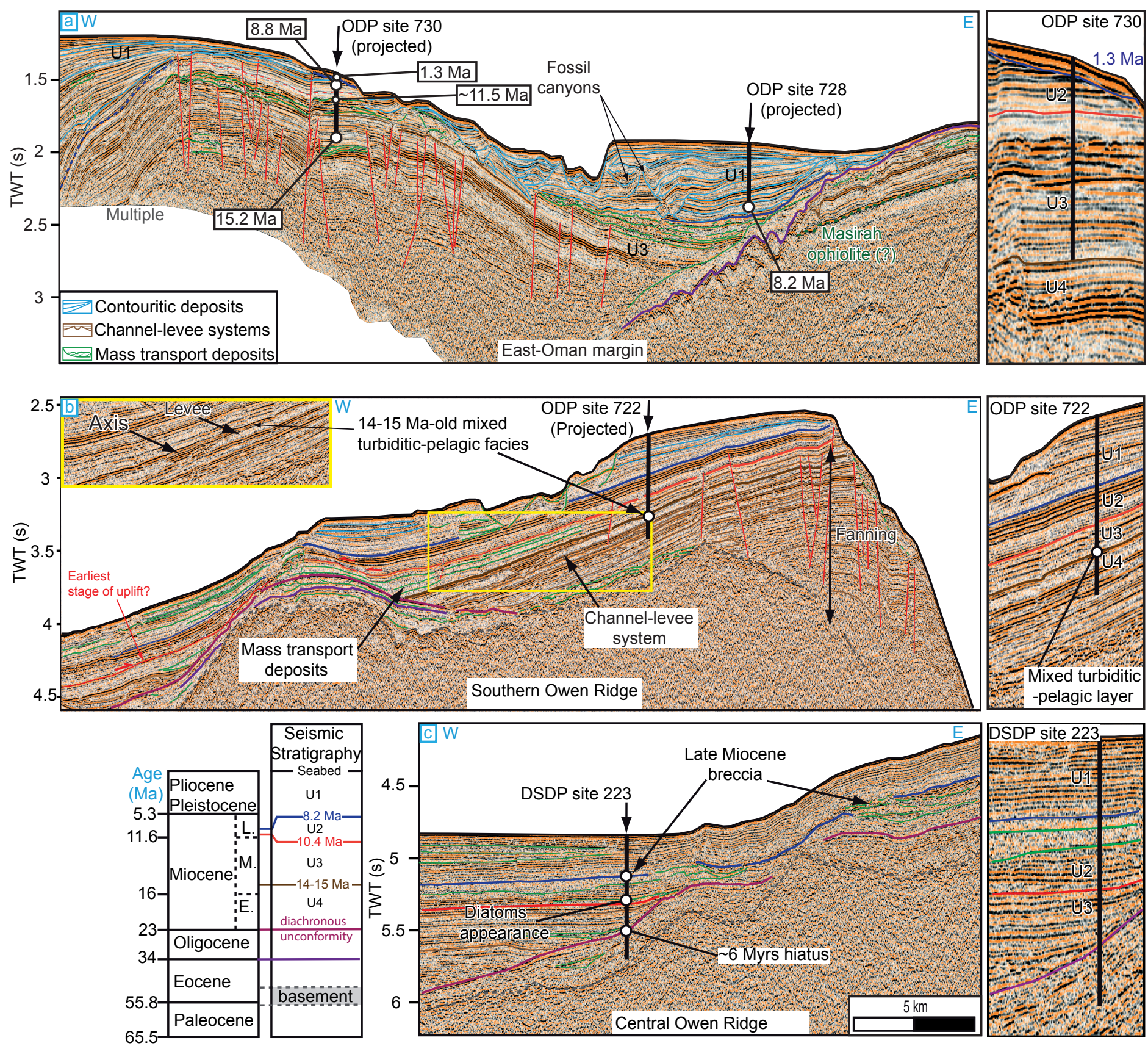

Figure 3 


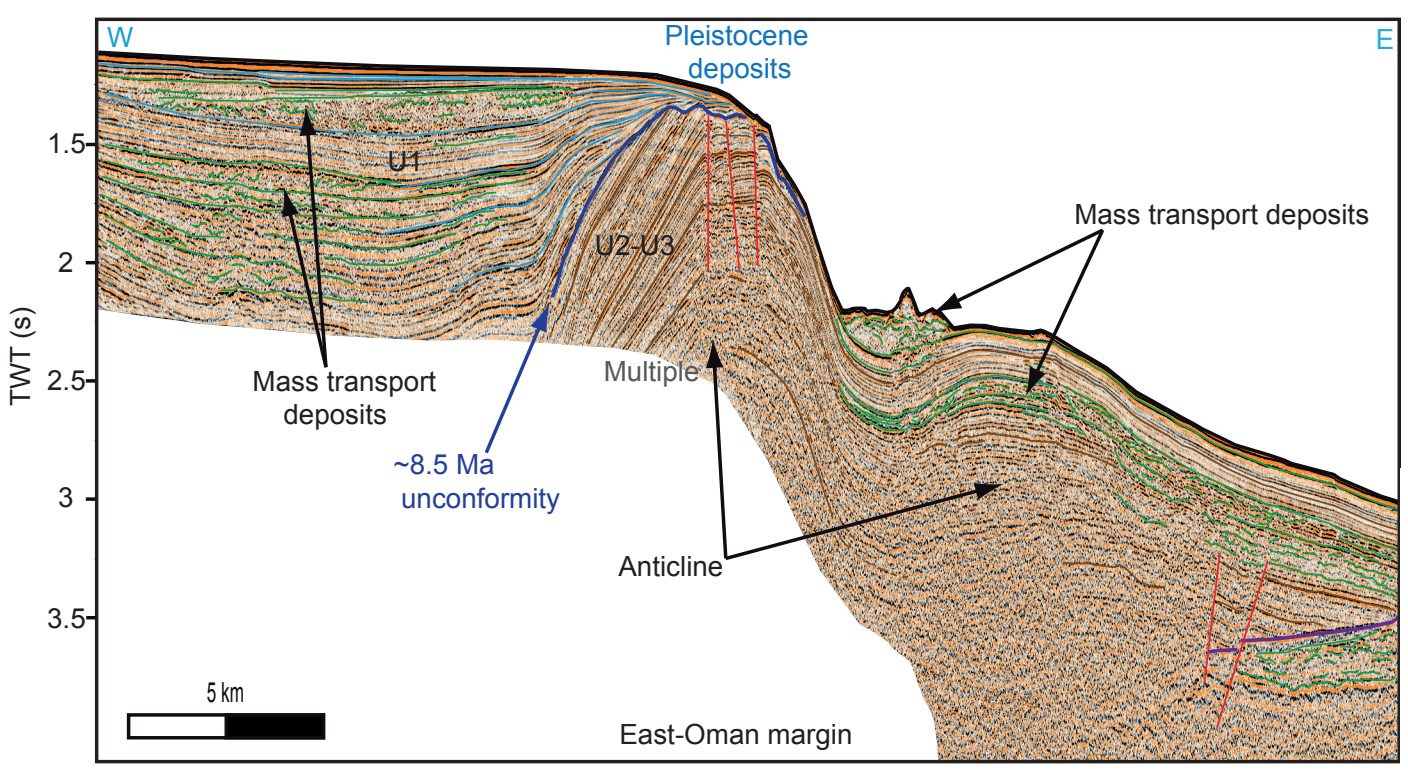

Figure 4 

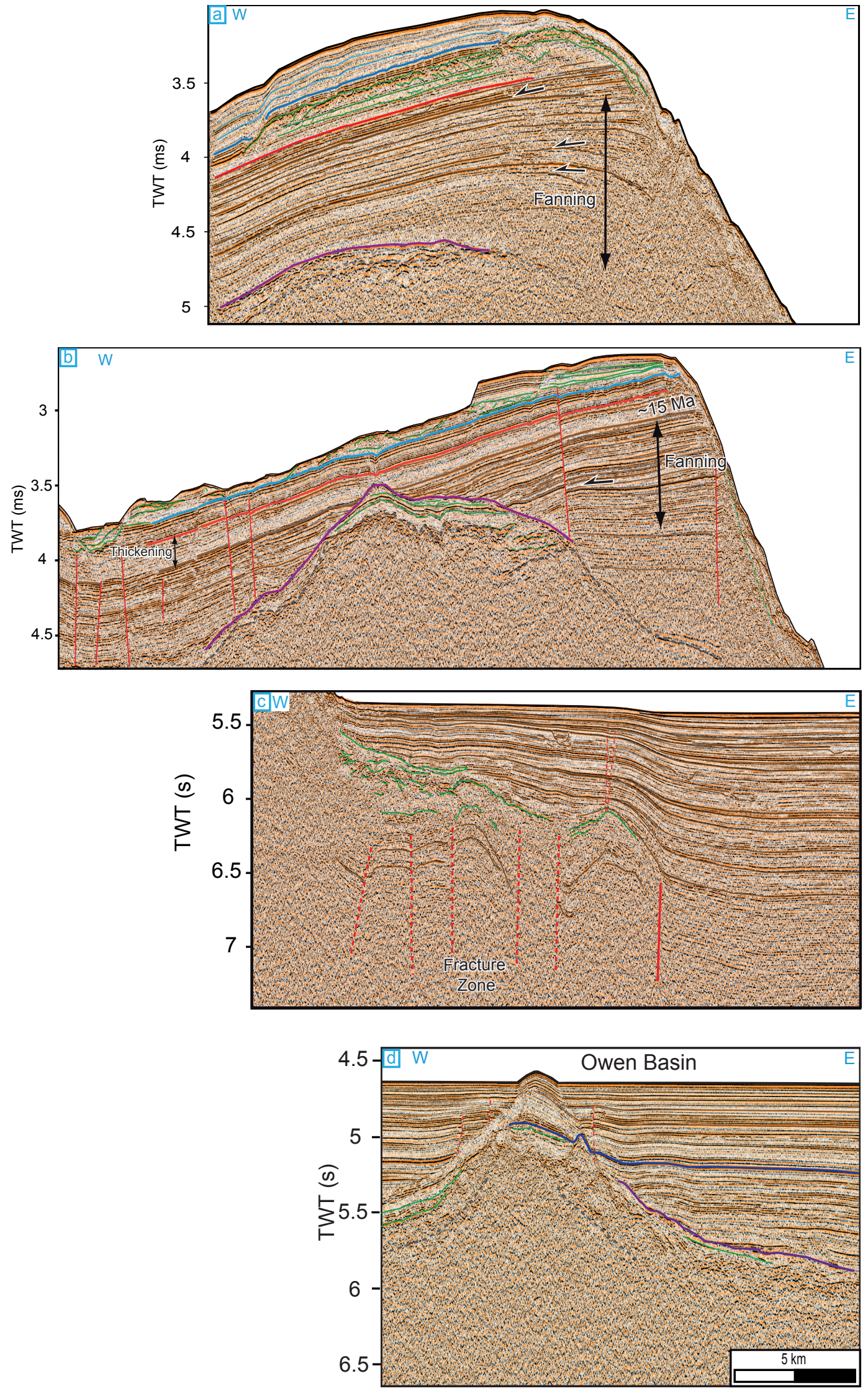

Figure 5 

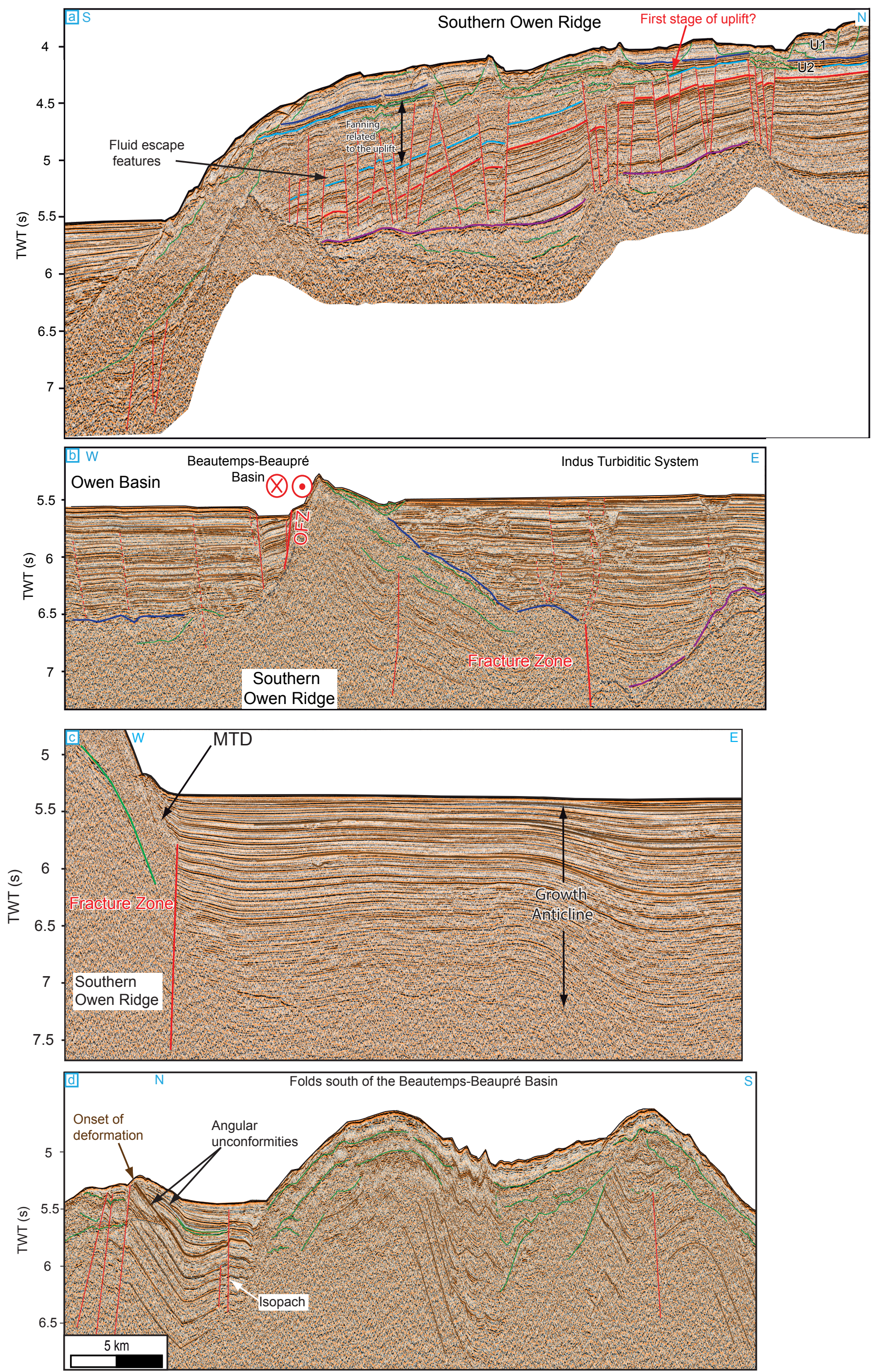

Figure 6 

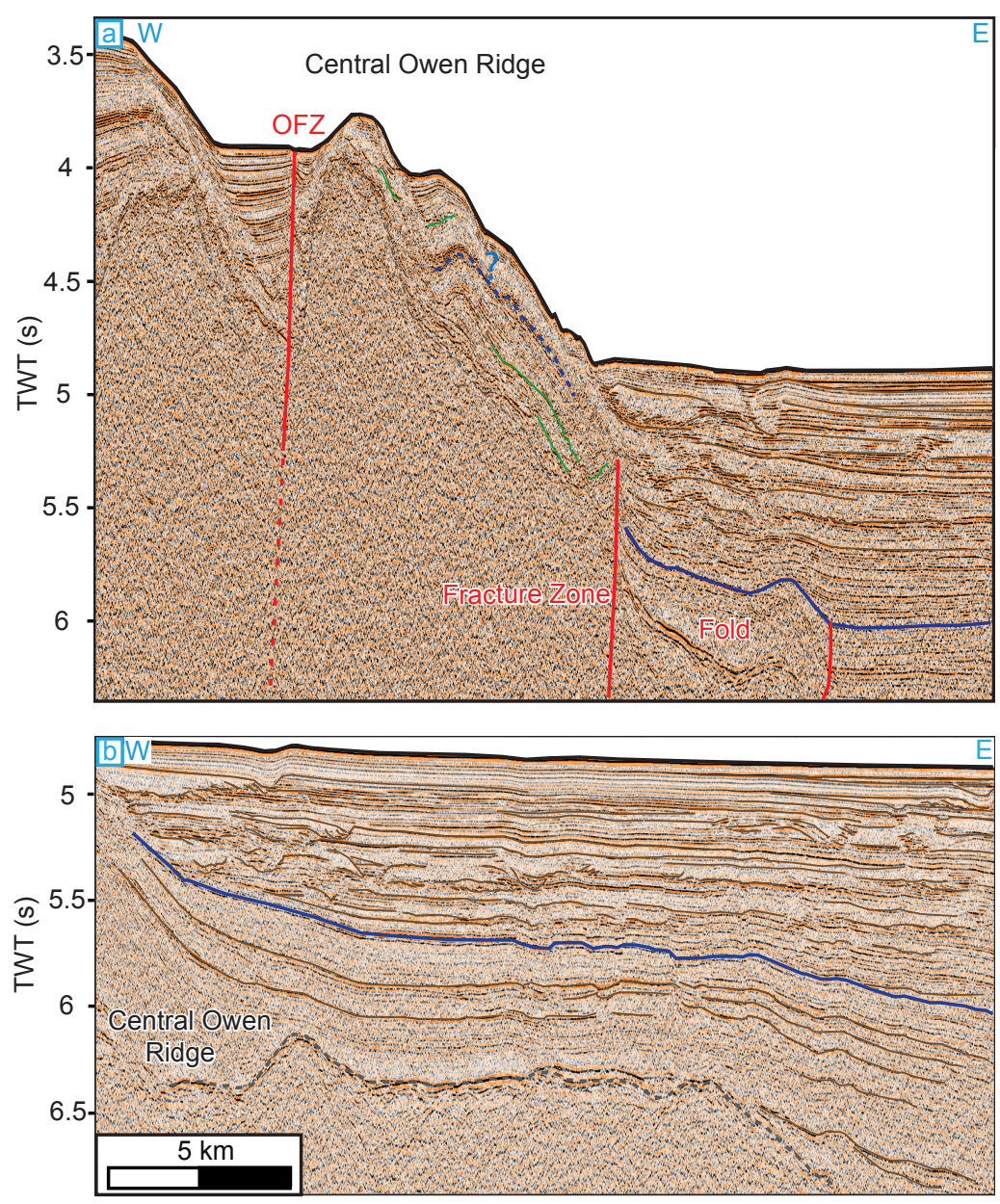

Figure 7 

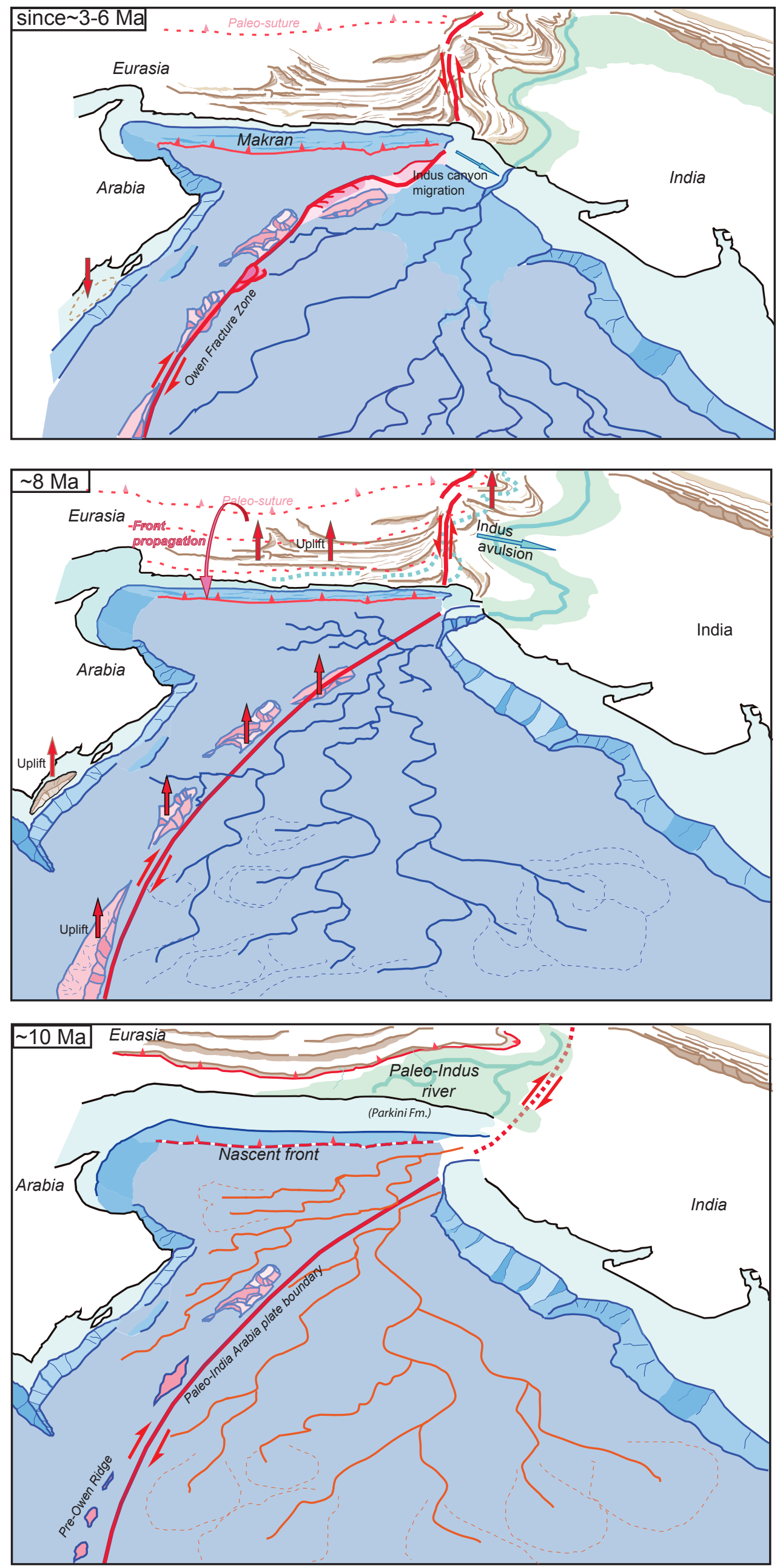

Figure 8 